\title{
A small-molecule inhibitor of the bacterial type III secretion system protects against in vivo infection with Citrobacter rodentium
}

\author{
Kyota Kimura $^{1,3}$, Masato Iwatsuki ${ }^{1,3}$, Takeshi Nagai ${ }^{2}$, Atsuko Matsumoto ${ }^{1}$, Yoko Takahashi ${ }^{1}$, Kazuro Shiomi ${ }^{1}$, \\ Satoshi Ōmura ${ }^{1}$ and Akio Abe ${ }^{1}$
}

The type III secretion system (T3SS) is highly conserved in many Gram-negative pathogenic bacteria and functions as an injector of bacterial proteins (effectors) into host cells. T3SSs are involved in establishing disease processes, but this machinery is not essential for bacterial growth or homeostasis. Thus, T3SS is expected to be a candidate therapeutic target, and inhibitors of T3SSs could potentially reduce virulence without causing bacterial death, thereby avoiding any subsequent development of resistance. We identified a linear polyketide compound, aurodox, as a specific T3SS inhibitor from the culture broth of Streptomyces sp. using a screening system for the T3SS-mediated hemolysis of enteropathogenic Escherichia coli (EPEC) established by our group. Aurodox strongly inhibited T3SS-mediated hemolysis with an $\mathrm{IC}_{50}$ value of $1.5 \mu \mathrm{g} \mathrm{ml}{ }^{-1}$ without affecting bacterial growth in liquid media. We also demonstrated that aurodox specifically inhibits the secretion of type IIIsecreted proteins such as EspB, EspF and Map, without affecting the expression of the housekeeping protein GroEL.

Furthermore, an in vivo infection study using mice clearly indicated that the administration of aurodox allowed the mice to survive a lethal dose of Citrobactor rodentium, a model bacterium for human pathogens such as EPEC. Thus, our in vivo study directly demonstrated for the first time that this putative T3SS inhibitor can be applied as a novel class of anti-infective agents. The Journal of Antibiotics (2011) 64, 197-203; doi:10.1038/ja.2010.155; published online 8 December 2010

Keywords: actinomycete; aurodox; Citrobacter rodentium; enteropathogenic Escherichia coli; type III secretion system

\section{INTRODUCTION}

Type III secretion systems (T3SSs) are highly conserved in many Gram-negative pathogenic bacteria, including Yersinia spp., Salmonella spp., Shigella spp., Pseudomonas aeruginosa, enteropathogenic Escherichia coli (EPEC), enterohemorrhagic E. coli (EHEC), Citrobacter rodentium and Chlamydia spp. ${ }^{1}$ T3SS is a needle-like secretion apparatus that delivers two types of secreted proteins, translocases and effectors, into host cells. The translocases are delivered into the host membrane through the T3SS, and build a physical pore, translocon, on the membrane, an event that is a prerequisite for the translocation of effectors (virulence factors) into host cells.

Effectors translocated through the T3SS interact with host factors to disturb the host's cellular physiology and homeostasis, ${ }^{2}$ leading to disease processes such as the development of attaching and effacing lesions ${ }^{3}$ in the case of infections with EPEC, a human pathogen causative of outbreaks of diarrhea in developing countries. ${ }^{4}$ EPEC is a prototype organism of the group of pathogenic bacteria that cause attaching and effacing lesions, and all genes responsible for attaching and effacing lesions are encoded within a 35.6-kb pathogenicity island referred to as the locus of enterocyte effacement (LEE). ${ }^{5}$ The LEE encodes the components of the T3SS apparatus, translocases and effectors (that is, EspB, EspD, Tir, EspF, Map, EspH and EspG). ${ }^{6}$ EspB and EspD translocases form a hetero complex on the host membrane and function as the translocon. ${ }^{7}$ Tir translocates on the host membrane through the T3SS and functions as a receptor for a bacterial surface protein, intimin, ${ }^{3}$ thereby allowing intimate attachment to the host intestine. EspF and Map have multiple functions; both effectors are translocated into the host mitochondria and are involved in the disruption of the tight junctions of epithelial cells. ${ }^{6}$ In summary, individual effectors carry out multiple tasks, and the synergistic effects of multiple effectors are involved in the pathogenesis of EPEC and related pathogens.

T3SSs are known to have an important role in establishing disease processes, as the virulence of pathogens has been shown to be greatly reduced in T3SS-deficient strains. ${ }^{8}$ For this reason, we and other groups focused on T3SS as a new target for anti-infective drugs.

\footnotetext{
${ }^{1}$ Department of Drug Discovery Sciences, Infection Control and Immunology, Kitasato Institute for Life Sciences, Graduate School of Infection Control Sciences, Kitasato University, Tokyo, Japan and 2Department of Microbiology and Immunology, Keio University School of Medicine, Tokyo, Japan 3These authors contributed equally to this work

Correspondence: Professor A Abe, Department of Drug Discovery Sciences, Infection Control and Immunology, Kitasato Institute for Life Sciences, Graduate School of Infection Control Sciences, Kitasato University, 5-9-1 Shirokane, Minato-ku, Tokyo 108-8641, Japan.

E-mail: abe@lisci.kitasato-u.ac.jp
}

Received 18 September 2010; revised 10 November 2010; accepted 11 November 2010; published online 8 December 2010 
Specific inhibitors of T3SS are expected to attenuate full bacterial virulence and inhibit infection processes without killing the bacteria. Thus, there would be little or no selective pressure for viability, which would potentially circumvent the development of resistance. To date, several small compounds have been developed as specific T3SS inhibitors. Caminosides, unique glycolipids, were isolated from the marine sponge Caminus sphaeroconia in a screen system in which Esp proteins, secreted from EPEC, were detected by SDS-polyacrylamide gel electrophoresis (SDS-PAGE). ${ }^{9} \quad$ Salicylidene acylhydrazide compounds inhibit the functioning of T3SS in Yersinia, ${ }^{10,11}$ Chlamydia, ${ }^{12-14}$ Shigella, $^{15}$ EHEC $^{16}$ and Salmonella. ${ }^{17,18}$ Furthermore, 2-imino-5-arylidene thiazolidinone inhibits T3SS function at the transcriptional level in Salmonella and in a plant pathogen, Pseudomonas syringae. ${ }^{19}$ We have isolated new compounds, guadinomines, produced by Streptomyces sp. K01-0509 as T3SS inhibitors of EPEC. ${ }^{20,21}$ These compounds are well characterized and effective in various T3SS-related pathogens in vitro, but have not yet been fully evaluated in an in vivo infection model. Here, we established a convenient screening system based on translocon-mediated hemolysis, and we identified linear polyketides as T3SS inhibitors obtained from the culture broths of Streptomyces spp. We also demonstrated for the first time the therapeutic effects of this linear polyketide in vivo.

\section{RESULTS}

\section{Experimental design for a screening system of T3SS inhibitors}

To identify small biological compounds as T3SS inhibitors, we designed a screening system based on translocon-mediated hemolysis (Figure 1). In EPEC, two translocases, EspB and EspD, are delivered into the host through the T3SS and build a physical pore on the host membrane. In general, EPEC exploits its T3SS to establish an intimate attachment to intestinal surfaces, but the T3SS also possesses the capacity to deliver translocases into the membrane of red blood cells (RBCs), which results in hemolysis and subsequently in the release

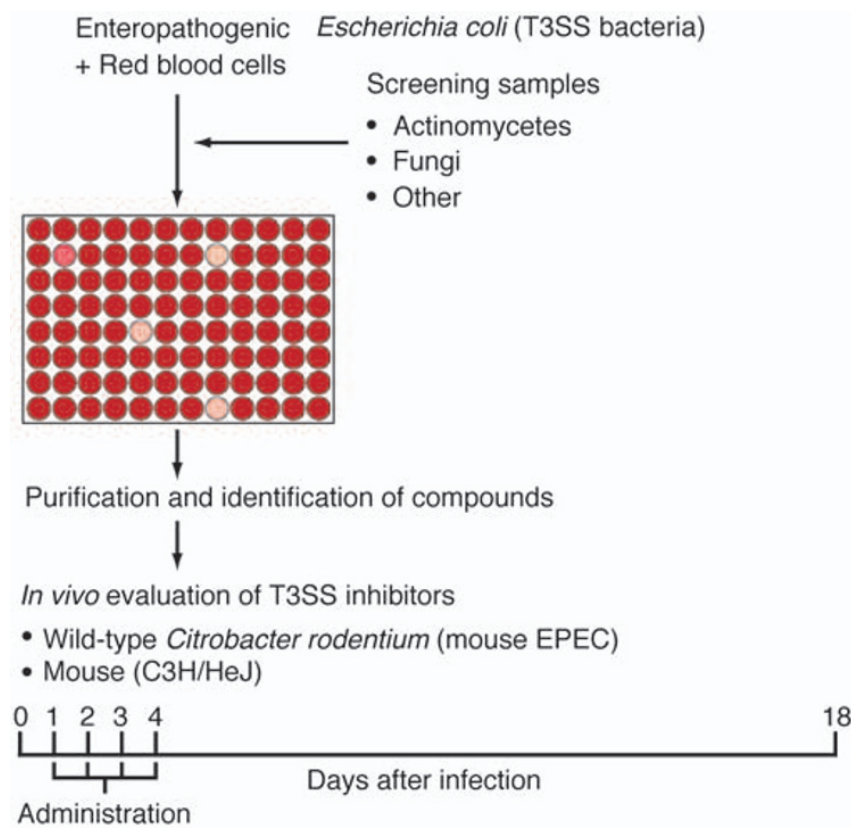

Figure 1 Experimental design for screening of T3SS inhibitors. Screening samples were evaluated by T3SS-mediated hemolysis. Presumed T3SS inhibitors were purified and identified, and the inhibitors were evaluated by in vivo infection study using $C$. rodentium. of hemoglobin into the surrounding fluid. ${ }^{7}$ Using T3SS-mediated hemolysis by translocon, we established a method to monitor protein transport through the T3SS (see Methods). Each sample was added to an EPEC-RBC suspension in a 96-well plate, and then the plate was incubated at $37^{\circ} \mathrm{C}$. After incubation, the bacteria-RBC suspensions were gently resuspended with phosphate-buffered saline (PBS), and the plate was centrifuged. The resulting supernatants containing hemoglobin were transferred to a new plate, in which the $\mathrm{OD}$ at $550 \mathrm{~nm}$ was measured with a microplate reader. Thus, the inhibition of T3SS-mediated hemolysis by compounds was easily evaluated by assessing the degree of hemoglobin release into the supernatant, and the inhibition (\%) of T3SS-mediated hemolysis was estimated by the OD value at $550 \mathrm{~nm}$ (see Methods).

\section{Identification of T3SS inhibitors}

We evaluated 13300 biological extracts (3055 actinomycetes, 4000 fungi and 6245 other organisms such as plants, invertebrates and so on). This screening process produced 151 initial hits. In this assay, antibacterial activity also affects T3SS-mediated hemolysis as pseudopositive results. Among the initial hits, 10 extracts ( 8 actinomycetes, 1 fungus and 1 plant) showed specific inhibition of hemolysis without affecting bacterial growth (data not shown). Two extracts of the actinomycete strains, Streptomyces spp. K06-0806 and K07-0034, showed potent inhibition of hemolysis. After fermentation and purification from Streptomyces spp. K06-0806 and K07-0034, active compounds were identified as two linear polyketide compounds, aurodox (Figure $2 \mathrm{a})^{22}$ and factumycin (Figure $2 \mathrm{~b}$ ), ${ }^{23}$ respectively. Using the purified compounds, we evaluated the corresponding levels of inhibition of T3SS-mediated hemolysis (Figures 2c-e). Although an antibacterial antibiotic, tetracycline, induced an inhibition of hemolysis $\left(\mathrm{IC}_{50}: 0.27 \mu \mathrm{g} \mathrm{m}^{-1}\right.$ ) (Figure $2 \mathrm{e}$ ), bacterial growth was reduced at the $\mathrm{IC}_{50}$ value of $0.27 \mu \mathrm{g} \mathrm{ml}^{-1}$, which suggests that the inhibition of hemolysis was the result of the antibacterial activity of tetracycline. In contrast, in amounts of up to $10 \mu \mathrm{g} \mathrm{ml}^{-1}$, aurodox did not affect bacterial growth (growth inhibition; $\mathrm{IC}_{50}: 40 \mu \mathrm{g} \mathrm{ml}^{-1}$ ), whereas clear inhibition of T3SS-mediated hemolysis $\left(\mathrm{IC}_{50}: 1.5 \mu \mathrm{g} \mathrm{ml}^{-1}\right.$ ) was observed. Interestingly, the $\mathrm{IC}_{50}$ value of an aurodox analog, factumycin, showed that the analog was 10 times less potent $\left(17 \mu \mathrm{g} \mathrm{ml}^{-1}\right)$ than aurodox, suggesting that the cyclized partial structure and/or the hydroxy group at $\mathrm{C}-2$ of the pyranose ring is critical to achieve the inhibition of T3SS function.

\section{Effect of aurodox on the secretion of T3SS-related proteins}

To analyze in more detail the inhibitory effects of aurodox on the secretion of type III-secreted proteins, an overnight culture of EPEC was inoculated in fresh Dulbecco's modified Eagle's medium, which allows for T3SS-dependent secretion, at an initial $\mathrm{OD}_{600}$ of 0.05 in the presence of aurodox. After a 6-h incubation, the bacterial whole-cell lysates and secreted proteins were prepared, and the resulting samples were analyzed by SDS-polyacrylamide gel electrophoresis using gels stained with Coomassie brilliant blue (Figure 3a). As expected, the bacterial whole-cell protein amount remained unaffected by the addition of aurodox $\left(\sim 5.0 \mu \mathrm{g} \mathrm{ml}^{-1}\right)$. In contrast, the amount of type III-secreted protein (EspA, EspB and EspD) was greatly reduced in the presence of aurodox. These inhibitory phenotypes were further confirmed by western blotting (Figure 3b). Again, aurodox reduced the secretion of Map and EspF effectors, as well as that of EspB. However, aurodox exerted no effect on the amount of housekeeping protein, GroEL, at the indicated concentrations (Figure 3b). These results clearly indicate that aurodox does possess the ability to inhibit the secretion of type III-secreted proteins without affecting bacterial growth. 
a

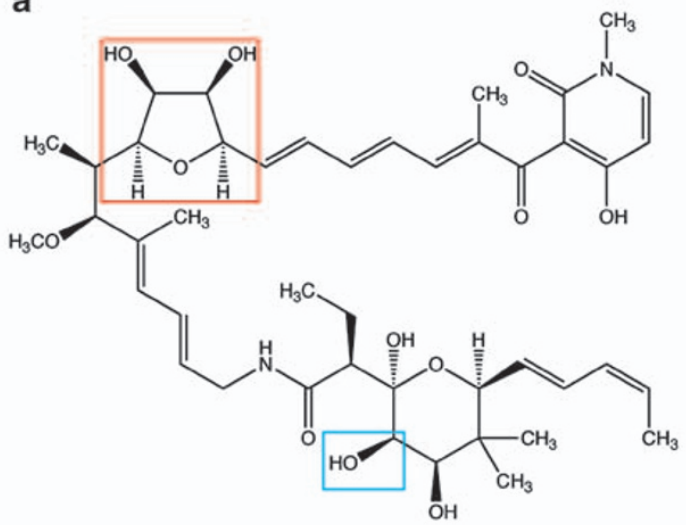

Aurodox b<smiles>C/C=C\C=C\[C@@]1(C)O[C@](O)([C@H](CC)C(=O)NC/C=C/C=C(\C)[C@@H](OC)[C@@H](C)[C@H](O)[C@H](O)/C=C\C=C\C=C\C=C(/C)C(=O)c2c(O)ccn(C)c2=O)C[C@@H](O)C1(C)C</smiles>

Factumycin
C

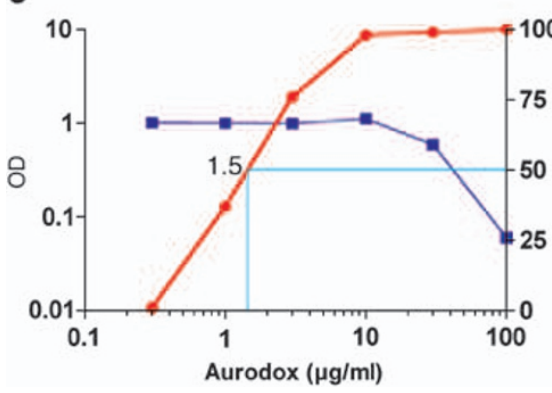

d

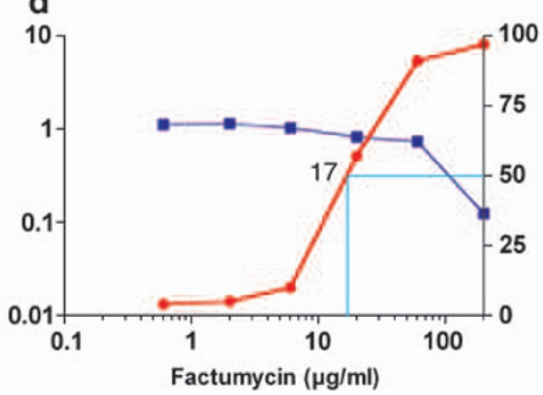

e

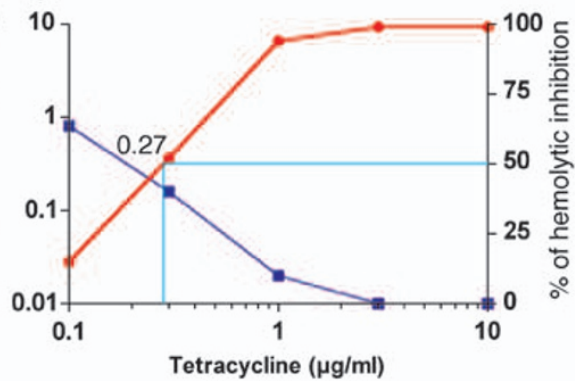

Figure 2 Identification of T3SS inhibitors. Chemical structures of the T3SS inhibitors, aurodox (a) and factumycin (b). Red and blue rectangles indicate the presumed active center of the T3SS inhibitory effect. (c-e) Inhibition of T3SS-mediated hemolysis by aurodox (c), factumycin (d) and tetracycline (e). EPEC induced hemolytic activity in a T3SS-dependent manner. Blue squares indicate EPEC growth (OD at $600 \mathrm{~nm}$ ) in the presence of these compounds. Red circles indicate an inhibition (\%) of T3SS-mediated hemolysis, as described in the Methods section.
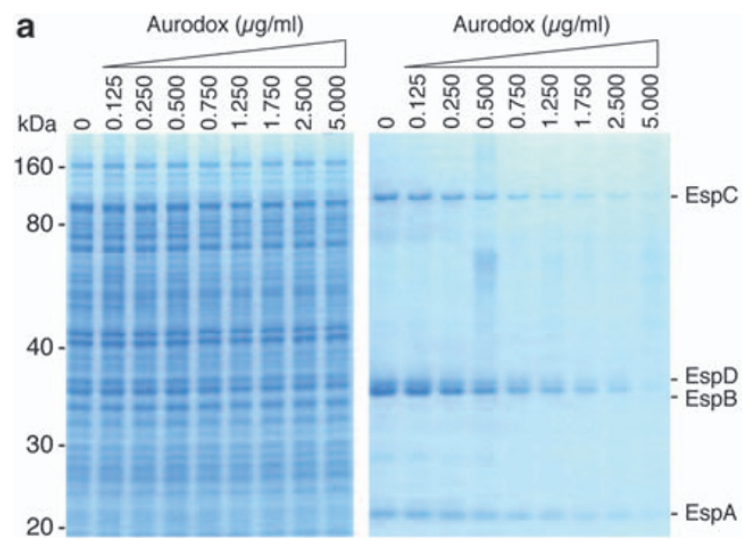

b

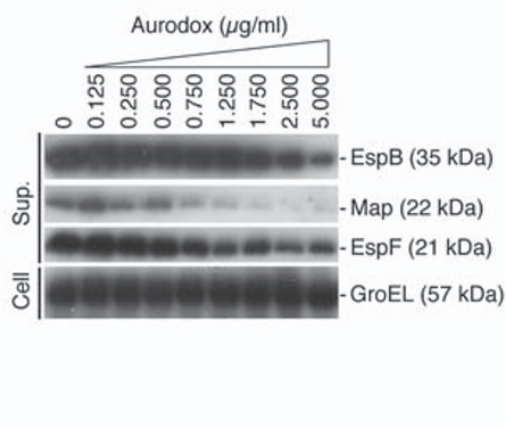

Figure 3 Effect of aurodox on the secretion of T3SS-related proteins. (a) EPEC was grown in the presence of different concentrations of aurodox. Bacterial whole-cell lysates (left panel) and secreted proteins (right panel) were prepared and subjected to SDS-polyacrylamide gel electrophoresis (12\%), followed by Coomassie brilliant blue staining. (b) Whole-cell lysates and secreted proteins were further analyzed by western blotting using anti-EspB, anti-EspF, anti-Map and anti-GroEL antibodies.

\section{Effect of aurodox in vivo}

To investigate whether aurodox might be effective in vivo, we designed an infection model using a mouse EPEC, $C$. rodentium, that causes colonic hyperplasia in a T3SS-dependent manner. Mice $(n=6)$ were orally infected with wild-type (WT) C. rodentium $\left(2 \times 10^{8}\right.$ per mouse), and then aurodox $\left(25 \mathrm{mg} \mathrm{kg}^{-1}\right)$, tetracycline $\left(200 \mathrm{mg} \mathrm{kg}^{-1}\right)$ or $10 \%$ DMSO (as negative control) was orally administered to the mice for 1-4 consecutive days after infection (Figure 1). To confirm the effect of T3SS on the $C$. rodentium virulence, mice $(n=6)$ were also orally infected with the EspB mutant $(\triangle \mathrm{EspB}$; a deficient strain of effector delivery of T3SS) of $C$. rodentium $\left(2 \times 10^{8}\right.$ per mouse). Survival of the mice was monitored for 18 days (Figure $4 \mathrm{a}$ ). None of the control mice (10\% DMSO) survived a lethal dose of WT bacteria, but all mice survived infection with the EspB mutant. Mice treated with a high dose of tetracycline $\left(200 \mathrm{mg} \mathrm{kg}^{-1}\right)$ survived through day 13 , but all mice had died from the infection with WT bacteria by day 18 . In contrast, all mice treated with aurodox $\left(25 \mathrm{mg} \mathrm{kg}^{-1}\right)$ survived infection with the WT bacteria. These results clearly indicate that 
the oral administration of aurodox contributed to the survival of these mice that had received a lethal dose of $C$. rodentium.

Furthermore, we evaluated the effect of aurodox on T3SS-dependent hyperplasia during the $C$. rodentium infection. $\mathrm{C} 3 \mathrm{H} / \mathrm{HeJ}$ mice $(n=3)$ that had been administered aurodox, tetracycline or DMSO were killed 9 days after infection, and macroscopic observation to identify typical pathological features of the large intestine was

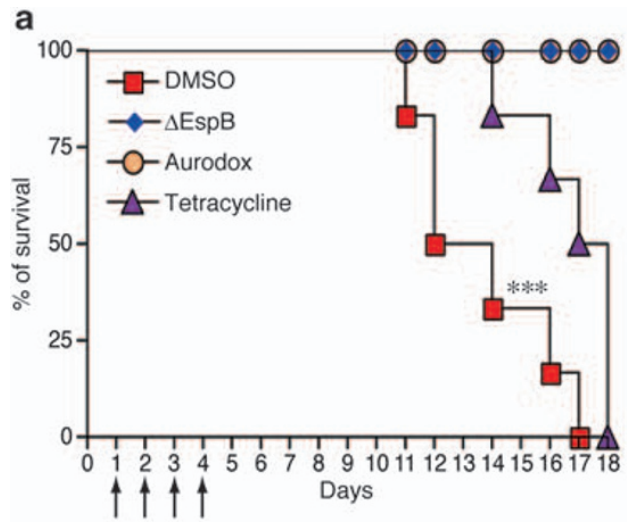

b

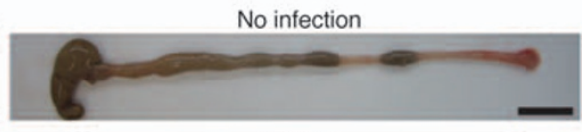

$\Delta \mathrm{EspB}$

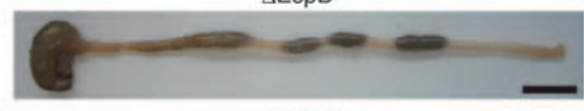

DMSO

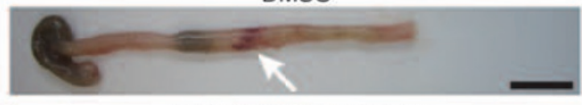

Tetracycline $(200 \mathrm{mg} / \mathrm{kg})$

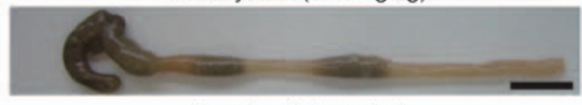

Aurodox $(25 \mathrm{mg} / \mathrm{kg})$

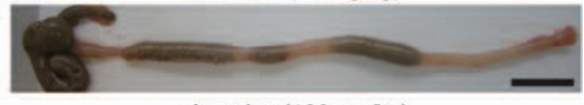

Aurodox (100 mg/kg)

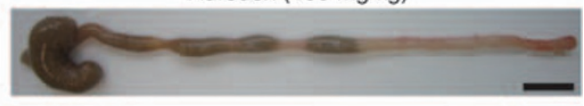

C

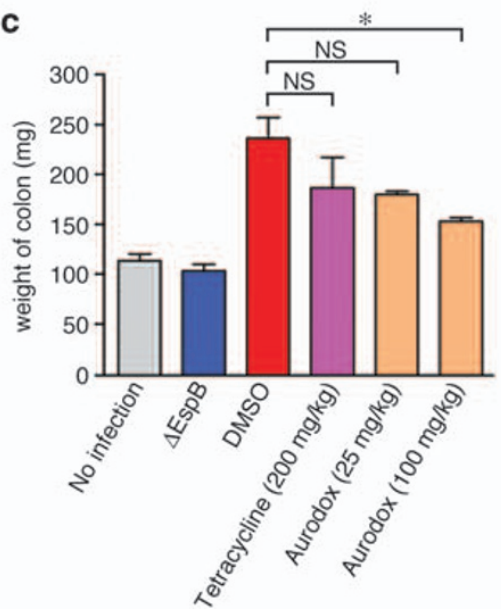

performed (Figure 4b). The intestine from mice infected with the EspB mutant was healthy and contained solidified feces. In contrast, bacteria-induced intestinal colitis (arrow) with less-solidified feces and decrease of colon length as a result of hyperplasia were observed in the intestine of mice treated with DMSO (mock administration) after infection. The intestines from mice treated with tetracycline or aurodox after infection with WT $C$. rodentium remained healthy with solidified feces, although some portions of the intestine were slightly swollen. These mice were further investigated for colonic weight as an indication of hyperplasia (see Methods) (Figure 4c). The colon weight of mice treated with aurodox $\left(100 \mathrm{mg} \mathrm{kg}^{-1}\right)$, but not with tetracycline $\left(200 \mathrm{mg} \mathrm{kg}^{-1}\right)$, was significantly less than that of mice that had received DMSO, the mock treatment. Collectively, these results strongly indicate that aurodox contributed to murine survival by the elimination of T3SS-mediated disease processes.

\section{DISCUSSION}

Bacterial T3SSs are conserved in many Gram-negative pathogens, and these structures possess the ability to deliver effectors into host cells, leading to infection. It is widely accepted that bacterial virulence is greatly reduced in T3SS-deficient strains, but bacterial growth is not affected by mutations of T3SS. Therefore, T3SS inhibitors are expected to specifically block bacterial disease processes without killing either the pathogens or normal bacterial flora. Salicylidene acylhydrazide and its derivatives have been identified as specific T3SS inhibitors, and these compounds are obtained by screening based on the transcriptional reporter system using $\operatorname{lu} x A B$, the luciferase-encoding hybrid gene in Vibrio harveyi. The gene luxAB fused with the promoter region of the $y o p E$ gene that encodes the Yersinia YopE effector protein was applied to the screening for inhibitors of regulators involved in T3SS-specific transcription. ${ }^{24}$ In contrast, 2-imino-5-arylidene thiazolidinone and its derivatives were obtained by screening based on the phospholipase A2 reporter system. The Salmonella typhimurium SipA effector was fused with Yersinia phospholipase A2, and the resulting SipA-phospholipase A2 fusion protein was secreted into the culture supernatant through T3SS. Active phospholipase has the ability to cleave specific substrates, and such cleavage results can be measured using a fluorometer. ${ }^{19}$ Many derivatives, including salicylidene acylhydrazide and 2-imino-5-arylidene thiazolidinone, have already been developed. Such compounds are known to inhibit T3SS function in Chlamydia, EHEC O157, Salmonella and Yersinia, but they have not yet been evaluated in vivo.

In this study, we established a semi-in vivo screening system based on T3SS-mediated hemolysis, and we obtained two compounds from the culture broths of Streptomyces spp. Both compounds were further purified and identified as linear polyketides, that is, aurodox and an aurodox analog, factumycin. Aurodox is known to be a protein

Figure 4 Effect of aurodox on in vivo infection. (a) $\mathrm{C} 3 \mathrm{H} / \mathrm{HeJ}$ mice ( $n=6$ each for $25 \mathrm{mg} \mathrm{kg}^{-1}$ aurodox (circles), $200 \mathrm{mg} \mathrm{kg}^{-1}$ tetracycline (triangles) and DMSO as control (squares)) were infected orally with $2 \times 10^{8}$ WT $C$. rodentium. The mice $(n=6)$ infected with $\Delta \mathrm{EspB}$ in the same manner were administered DMSO (diamonds). The compounds or DMSO was orally administered to infected and mock-infected mice for 1-4 days in a row, and then survival was monitored. Note that data for aurodox treatment (100 $\mathrm{mg} \mathrm{kg}^{-1}$ ) have not been not inserted in the graph, but all mice survived infection with the WT bacteria. ${ }^{* * *} P<0.0005$ using the log-rank test. (b) At 9 days after infection, the mice $(n=3)$ were killed and colons were observed. The arrow indicates colitis. Note that decrease of colon length as a result of extensive hyperplasia was observed in the intestine of mice treated with DMSO (mock administration) after infection. $B a r=1.0 \mathrm{~cm}$. (c) Colon weight $\left(5.5 \mathrm{~cm}\right.$ from the rectum) was measured. ${ }^{*} P<0.05$. NS: no significance. 
Table 1 Antibacterial activity of aurodox and factumycin

Inhibition zone ( $\mathrm{mm})$ at $10 \mu \mathrm{g}$ per 6-mm disk

\begin{tabular}{lrc}
\cline { 2 - 3 } Test organism & Aurodox & Factumycin \\
\hline Bacillus subtilis & 10 & - \\
Staphylococcus aureus & 9 & - \\
Micrococcus luteus & 17 & 11 \\
Mycobacterium smegmatis & 8 & - \\
Escherichia coli & 13 & - \\
Pseudomonas aeruginosa & - & 22 \\
Xanthomonas campestris & 22 & - \\
Bacteroides fragilis & - & \\
\hline
\end{tabular}

biosynthesis inhibitor, similar to tetracycline..$^{25,26}$ It is known that the inhibition of protein biosynthesis by aurodox is caused by its binding to the active domain of the bacterial elongation factor $\mathrm{Tu}^{27}$ Thus, aurodox has antibacterial activity by binding elongation factor Tu, which may affect T3SS-mediated hemolysis. However, aurodox showed specific inhibition of T3SS-mediated hemolysis ( $\mathrm{IC}_{50}: 1.5 \mu \mathrm{g} \mathrm{ml}^{-1}$ ) without affecting bacterial growth (Figure 2c). In contrast, although tetracycline inhibits hemolytic activity $\left(\mathrm{IC}_{50}\right.$ : $0.27 \mu \mathrm{g} \mathrm{ml}^{-1}$ ) (Figure 2e), bacterial growth is also inhibited at the same $\mathrm{IC}_{50}$ value. These results strongly suggest that the mechanism of inhibition of T3SS-mediated hemolysis by aurodox differs from that of tetracycline. Interestingly, aurodox and factumycin were found to have similar levels of E. coli antibacterial activity (Table 1). However, the inhibitory activity of aurodox was 10 times higher than that of factumycin (Figures $2 \mathrm{c}$ and d), suggesting that both the cyclized partial structure and the hydroxy group in aurodox (Figure 2a) may serve as active centers for T3SS inhibition and antibacterial activity in some Gram-positive bacteria (Table 1).

Thus, the linear polyketide aurodox appears to inhibit T3SS function. Although we could not clarify its mechanism of action, aurodox inhibited the secretion of some LEE-encoded proteins (EspA, EspB, EspD, EspF and Map) and EspC, a member of the immunoglobulin A protease family of autotransporters (Figure 3). It is known that the expression of LEE-encoded proteins and EspC is coordinately regulated by an LEE-encoded regulator, Ler, ${ }^{28}$ and a BipA regulator, ${ }^{29}$ a member of the ribosome binding GTPase family. Such findings suggest that aurodox inhibits the expression of genes under the control of Ler and/or BipA. Similarly, salicylidene acylhydrazide also inhibits the transcription of T3SS and of other pathogenicity islands, suggesting that both aurodox and salicylidene acylhydrazide inhibit the global regulators involved in the regulation of horizontally acquired pathogenicity islands.

We demonstrated for the first time that the administration of a T3SS inhibitor contributed to the survival of mice that had received a lethal dose of $C$. rodentium. To our surprise, mice treated with a high dose of tetracycline $\left(200 \mathrm{mg} \mathrm{kg}^{-1}\right)$ survived through day 13 , but by day 18 none of the tetracycline-treated mice had survived infection with the WT bacteria. In contrast, all mice treated with aurodox (25 and $100 \mathrm{mg} \mathrm{kg}^{-1}$ ) survived the WT infection. Furthermore, significantly lower colon weight (used as an indicator of pathological hyperplasia) was seen in mice treated with high-dose aurodox $\left(100 \mathrm{mg} \mathrm{kg}^{-1}\right)$ than in the mock-treatment group. Collectively, the results demonstrated that aurodox, but not tetracycline, exhibits the ability to inhibit T3SS-mediated hyperplasia triggered by C. rodentium infection.

We evaluated 13300 biological extracts, and the resulting 10 extracts showed inhibition of T3SS-mediated hemolysis. We detected five aurodox/factumycin group compounds from 10 extracts. Several screening systems have been developed by other research groups, but aurodox derivatives could not be detected in such an evaluation. Thus, the present semi-in vivo screening system may be beneficial for the development of a new category of T3SS inhibitors, and the linear polyketide aurodox may provide the starting material for novel T3SS inhibitors that could be effective in vivo.

\section{METHODS}

\section{Bacterial strains}

EPEC E2348/6930 WT and CesT mutant strains ${ }^{31}$ were used as the probe strain for T3SS-mediated hemolytic activity. C. rodentium DBS100 ${ }^{32}$ and EspB mutant ${ }^{33}$ strains were used for the in vivo infection study. The following Gram-positive and Gram-negative bacterial strains were used for the assay of antibacterial activity: Bacillus subtilis ATCC6633, Staphylococcus aureus ATCC6538P, Micrococcus luteus ATCC9341, Mycobacterium smegmatis ATCC607, E. coli NIHJ, P. aeruginosa IFO3080, Xanthomonas camestris KB88 and Bacteroides fragilis ATCC23745.

\section{Assay of antibacterial activity}

Antibacterial activity was measured using the paper disk method $(6 \mathrm{~mm}$, Advantec, Tokyo, Japan) and test samples. ${ }^{34}$ Paper disks were placed on agar plates $(0.8-1.5 \%)$ that had been swabbed with test bacteria, and the inoculated plates were incubated for $24 \mathrm{~h}$ at $37^{\circ} \mathrm{C}$. The following media were used on the agar plates: B. subtilis (Davis synthetic medium $\left(0.7 \% \mathrm{~K}_{2} \mathrm{HPO}_{4}, 0.2 \% \mathrm{KH}_{2} \mathrm{PO}_{4}\right.$, $0.5 \%$ sodium citrate, $0.1 \%$ ammonium sulfate, $0.2 \%$ glucose and $0.01 \% \mathrm{MgSO}_{4}$ $\left.7 \mathrm{H}_{2} \mathrm{O}\right)$ ), S. aureus (nutrient agar $(0.5 \%$ peptone, $0.5 \%$ meat extract and $0.8 \%$ agar)), M. luteus ATCC9341 (nutrient agar), M. smegmatis ATCC607 (Waksman medium $(0.5 \%$ peptone, $0.5 \%$ meat extract, $0.3 \% \mathrm{NaCl}$ and $1.0 \%$ glucose)), E. coli NIHJ (nutrient agar), P. aeruginosa IFO3080 (nutrient agar), X. camestris KB88 (nutrient agar) and B. fragilis ATCC23745 (5.0\% GAM broth medium).

\section{Measurement of T3SS-dependent hemolytic activity}

T3SS-mediated hemolytic activity was measured as follows: An EPEC CesT mutant, $\Delta$ CesT, a defective strain of chaperon for the Tir effector, has low virulence but retains the ability to elicit T3SS-mediated hemolytic activity. One colony of the EPEC $\Delta$ CesT strain was inoculated in $5 \mathrm{ml}$ of Lysogeny broth liquid medium and incubated at $37^{\circ} \mathrm{C}$ for $16 \mathrm{~h}$ without shaking. An overnight culture $(0.5 \mathrm{ml})$ was used to inoculate $50 \mathrm{ml}$ of fresh M9 medium $(0.4 \%$ glucose, $0.68 \% \mathrm{Na}_{2} \mathrm{HPO}_{4}, 0.3 \% \mathrm{KH}_{2} \mathrm{PO}_{4}, 0.05 \% \mathrm{NaCl}, 0.1 \% \mathrm{NH}_{4} \mathrm{Cl}$ and $0.012 \% \mathrm{MgSO}_{4}$ ) containing $0.1 \%$ casamino acids and $44 \mathrm{~mm}$ of sodium bicarbonate; cells were grown at $37^{\circ} \mathrm{C}$ in the presence of $5 \% \mathrm{CO}_{2}$ for $4 \mathrm{~h}$. The bacterial culture was then centrifuged, and the resulting bacterial pellets were resuspended in $7 \mathrm{ml}$ of $\mathrm{M} 9$ medium, and $45 \mu \mathrm{l}$ of bacterial suspension was applied in a 96-well cell culture cluster (Costar, New York, NY, USA). Each screening sample was dissolved in $10 \mu \mathrm{l}$ of M9 medium and added to the bacterial suspension. Sheep's whole blood $(2 \mathrm{ml})$ (Nippon Bio-supply Center, Tokyo, Japan) was gently washed with PBS and the cells were resuspended in $4 \mathrm{ml}$ of $\mathrm{M} 9$ medium. The resulting $\mathrm{RBC}$ suspension $(45 \mu \mathrm{l})$ was applied to the 96-well microtiter plate. Bacteria-RBC suspensions added to the screening samples were centrifuged to facilitate bacterial contact with RBCs, and then the samples were incubated at $37^{\circ} \mathrm{C}$ for $1.5 \mathrm{~h}$. After incubation, the bacteria-RBC suspensions were gently resuspended with an additional $100 \mu \mathrm{l}$ PBS, and then the plates were centrifuged. The resulting supernatants $(100 \mu \mathrm{l})$ were transferred to new plates, in which the OD at $550 \mathrm{~nm}$ was measured using a microplate reader (Bio-Instruments, New Brighton, MN, USA). The following formula was used for the inhibition of T3SS-mediated hemolysis:

Inhibition of T3SS-mediated hemolysis $(\%)=(1-(\mathrm{A}-\mathrm{C}) /(\mathrm{B}-\mathrm{C})) \times 100$

$\mathrm{A}: \mathrm{OD}_{550}$ for the supernatant of the bacteria-RBC suspension with the screening sample;

$\mathrm{B}: \mathrm{OD}_{550}$ for the supernatant of the bacteria-RBC suspension without the screening sample;

$\mathrm{C}: \mathrm{OD}_{550}$ for the supernatant of the PBS-RBC suspension. 


\section{Taxonomic studies of the aurodox-producing strains}

The international Streptomyces project (ISP) media recommended by Shirling and Gottlieb ${ }^{35}$ were used for the investigatation of the cultural characteristics of the aurodox-producing strains. Culture characteristics were observed after incubation for 2 weeks at $27^{\circ} \mathrm{C}$, and morphological properties were observed with a scanning electron microscope (model JSM-5600, JEOL, Akishima, Tokyo, Japan). Isomers of diaminopimelic acid were determined by the method of Becker et al. ${ }^{36}$ Menaquinones were extracted and purified by the method of Collins et $a l^{37}$ and then analyzed by HPLC equipped with a Capcell Pak C18 column (Shiseido, Tokyo, Japan). ${ }^{38}$ Strains K06-0806 and K07-0034 were isolated from soil samples collected in Bangladesh. Strain K06-0806 grew well on oatmeal agar (ISP3) and peptone-yeast extract-iron agar (ISP6), and produced abundant aerial mycelia on ISP3, inorganic salts-starch agar (ISP4) and tyrosine agar (ISP7). The spore chains were looped. The spores were cylindrical in shape, $0.6 \times 1.2 \mu \mathrm{m}$ in size and had a smooth surface. Strain K070034 grew well on ISP3, and produced aerial mycelia on yeast extract-malt extract agar (ISP2) and ISP3. The spore chains were spiral. The smoothsurfaced spores were cylindrical and $0.8 \times 1.0 \mu \mathrm{m}$ in size. Strains K06-0806 and K07-0034 contained LL-DAP in the whole-cell hydrolysis. The major menaquinones of both strains were MK-9 $\left(\mathrm{H}_{6}\right)$ and MK-9 $\left(\mathrm{H}_{8}\right)$. On the basis of the taxonomic properties described above, strains K06-0806 and K07-0034 were determined to belong to the genus Streptomyces.

\section{Fermentation and isolation of aurodox and factumycin}

Streptomyces sp. K06-0806 was grown and maintained on an agar slant consisting of $1.0 \%$ starch, $0.3 \% \mathrm{NZ}$ amine, $0.1 \%$ yeast extract, $0.1 \%$ meat extract, $1.2 \%$ agar and $0.3 \% \mathrm{CaCO}_{3}$. A loop of spores of Streptomyces sp. K06-0806 was inoculated into $100 \mathrm{ml}$ of the seed medium consisting of $2.4 \%$ starch, $0.1 \%$ glucose, $0.3 \%$ peptone, $0.3 \%$ meat extract, $0.5 \%$ yeast extract and $0.3 \% \mathrm{CaCO}_{3}$ (adjusted to $\mathrm{pH} 7.0$ before sterilization) in a $500-\mathrm{ml}$ Erlenmeyer flask. The contents of the inoculated flask were incubated on a rotary shaker ( 210 r.p.m. $\mathrm{min}^{-1}$ ) at $27^{\circ} \mathrm{C}$ for 3 days. A 1 -ml portion of the seed culture was transferred into $100 \mathrm{ml}$ of the culture medium consisting of $2.0 \%$ glycerol, $1.0 \%$ glucose, $0.5 \%$ corn steep powder, $1.0 \%$ defatted soybean, $0.2 \%$ meat extract, $0.01 \% \mathrm{MgSO}_{4} 7 \mathrm{H}_{2} \mathrm{O}$ and $0.2 \% \mathrm{CaCO}_{3}$ (adjusted to $\mathrm{pH} 7.0$ before sterilization) in a 500-ml Erlenmeyer flask (total: four flasks), and fermentation was carried out on a rotary shaker $\left(210\right.$ r.p.m. $\left.\mathrm{min}^{-1}\right)$ at $27^{\circ} \mathrm{C}$ for 7 days. EtOH $(400 \mathrm{ml})$ was added to the 7-day-old culture broth $(400 \mathrm{ml})$, followed by centrifugation at 3000 r.p.m. The supernatant was concentrated under reduced pressure to remove $\mathrm{EtOH}$, and then passed through an ODS column $(16 \phi \times 130 \mathrm{~mm}$, Senshu Scientific, Tokyo, Japan). After washing the samples in water and $30 \%$ acetonitrile $(60 \mathrm{ml})$, the active material was eluted with $60 \%$ acetonitrile $(60 \mathrm{ml})$, followed by concentration in vacuo and lyophilization to yield a brown material $(75.6 \mathrm{mg})$. A portion $(9 \mathrm{mg})$ of the material was dissolved in a small amount of $\mathrm{MeOH}$ and purified by HPLC on a Pegasil ODS column (20 $\phi \times 250 \mathrm{~mm}$, Senshu Scientific) with $70 \% \mathrm{MeOH}$ at a rate of $7 \mathrm{ml} \mathrm{min}^{-1}$; aurodox was monitored at UV $210 \mathrm{~nm}$. The active fraction at a retention time of $12 \mathrm{~min}$ was concentrated in vacuo to dryness to yield pure aurodox $(3.34 \mathrm{mg})$ as a yellow powder.

Streptomyces sp. K07-0034 was grown and maintained on an agar slant consisting of $1.0 \%$ starch, $0.3 \% \mathrm{NZ}$ amine, $0.1 \%$ yeast extract, $0.1 \%$ meat extract, $1.2 \%$ agar and $0.3 \% \mathrm{CaCO}_{3}$. A loop of spores of Streptomyces sp. K07-0034 was inoculated into $100 \mathrm{ml}$ of the seed medium described above in a 500-ml Erlenmeyer flask. The inoculated flask was placed on a rotary shaker ( 210 r.p.m. $\mathrm{min}^{-1}$ ) for incubation at $27^{\circ} \mathrm{C}$ for 3 days. A 1 -ml portion of the seed culture was transferred into $100 \mathrm{ml}$ of the culture medium (described above) in a 500-ml Erlenmeyer flask (total: 33 flasks), and fermentation was carried out on a rotary shaker $\left(210\right.$ r.p.m. $\mathrm{min}^{-1}$ ) at $27^{\circ} \mathrm{C}$ for 5 days. The 5-day-old culture broth (3.31) was extracted with $\mathrm{EtOH}$ (3.31), followed by centrifugation at 3000 r.p.m. The supernatant was concentrated under reduced pressure to remove $\mathrm{EtOH}$, and extraction with ethyl acetate was performed in triplicate ( $\mathrm{pH} 6)$. The ethyl acetate extract $(783 \mathrm{mg})$ was washed with $n$-hexane, and the insoluble material $(216 \mathrm{mg})$ was dissolved in a small amount of $\mathrm{MeOH}$ and purified by HPLC on a XBridge C18 column $(10 \phi \times 250 \mathrm{~mm}$, Waters, Milford, MA, USA) with $59 \% \mathrm{MeOH} / 0.2 \%$ aqueous AcOH buffer (pH 4.75) at a rate of $4 \mathrm{ml} \mathrm{min}^{-1}$. Factumycin was monitored at UV $210 \mathrm{~nm}$. The active fraction at a retention time of $26 \mathrm{~min}$ was concentrated in vacuo to dryness to afford crude factumycin, which was subsequently purified on a silica gel column $(10 \phi \times 270 \mathrm{~mm}$, Merck, Whitehouse station, NJ, USA $)$ using a $\mathrm{CHCl}_{3}-\mathrm{MeOH}$ system. The fraction $\left(\mathrm{CHCl}_{3}-\mathrm{MeOH}=1: 1\right)$ was concentrated in vacuo to dryness to afford pure factumycin $(1.2 \mathrm{mg})$ as a yellow powder.

\section{Identification of aurodox and factumycin}

Aurodox ${ }^{39}$ and factumycin ${ }^{40}$ were identified by comparison of NMR spectral data with data reported in the literature and 2D NMR analysis. The NMR spectra were measured on a Varian XL-400 spectrometer or a Varian Inova 600 spectrometer (Varian, Palo Alto, CA, USA) with ${ }^{1} \mathrm{H}$ NMR at 400 or $600 \mathrm{MHz}$, and ${ }^{13} \mathrm{C}$ NMR at 100 or $150 \mathrm{MHz}$ in $\mathrm{CD}_{3} \mathrm{OD}$. The chemical shifts are referenced to $\mathrm{CD}_{3} \mathrm{OD}$ (3.30 p.p.m.) in the ${ }^{1} \mathrm{H}$ NMR spectra, and to $\mathrm{CD}_{3} \mathrm{OD}$ (49.0 p.p.m.) in the ${ }^{13} \mathrm{C}$ NMR spectra. FAB mass spectra were measured on a JEOL JMS AX-505 HA mass spectrometer (JEOL). Aurodox: yellow powder; HR-negativeFAB-MS $m / z 809.4253$ for $[\mathrm{M}-\mathrm{H}]^{-}$(calcd. for $\mathrm{C}_{44} \mathrm{H}_{61} \mathrm{~N}_{2} \mathrm{O}_{12}, 809.4225$ ); ${ }^{1} \mathrm{H}$ $\operatorname{NMR}\left(\mathrm{CD}_{3} \mathrm{OD}\right) \delta 0.83(3 \mathrm{H}, \mathrm{d}, 7 \mathrm{~Hz}), 0.93(3 \mathrm{H} \mathrm{x} 2, \mathrm{~s}), 0.94(3 \mathrm{H}, \mathrm{t}, 7 \mathrm{~Hz}), 1.68$ $(3 \mathrm{H}, \mathrm{s}), 1.71(2 \mathrm{H}, \mathrm{m}), 1.75(3 \mathrm{H}, \mathrm{d}, 7 \mathrm{~Hz}), 2.00(3 \mathrm{H}, \mathrm{s}), 2.18(1 \mathrm{H}, \mathrm{m}), 2.83$ $(1 \mathrm{H}, \mathrm{t}, 7 \mathrm{~Hz}), 3.16(3 \mathrm{H}, \mathrm{s}), 3.30(1 \mathrm{H}, \mathrm{m}), 3.30(3 \mathrm{H}, \mathrm{s}), 3.58(1 \mathrm{H}, \mathrm{d}, 3.5 \mathrm{~Hz}), 3.66$ $(1 \mathrm{H}, \mathrm{d}, 3.5 \mathrm{~Hz}), 3.68(1 \mathrm{H}, \mathrm{dd}), 3.91(1 \mathrm{H}, \mathrm{dd}, 18,9 \mathrm{~Hz}), 4.21(1 \mathrm{H}, \mathrm{dd}, 2.4$, $2.4 \mathrm{~Hz}), 4.22(1 \mathrm{H}, \mathrm{d}), 4.28(1 \mathrm{H}, \mathrm{m}), 4.30(1 \mathrm{H}, \mathrm{m}), 5.34(1 \mathrm{H}, \mathrm{tq}), 5.46(1 \mathrm{H}, \mathrm{dq})$, $5.63(1 \mathrm{H}, \mathrm{m}), 5.68(1 \mathrm{H}, \mathrm{m}), 5.82(1 \mathrm{H}, \mathrm{d}), 5.97(1 \mathrm{H}, \mathrm{d}), 5.98(1 \mathrm{H}, \mathrm{m}), 6.00(1 \mathrm{H}$, $\mathrm{m}), 6.52(1 \mathrm{H}, \mathrm{m}), 6.40(1 \mathrm{H}, \mathrm{m}), 6.56(1 \mathrm{Hx} 2, \mathrm{~m}), 6.60(1 \mathrm{H}, \mathrm{m}), 7.31(1 \mathrm{H}, \mathrm{d})$; ${ }^{13} \mathrm{C}$ NMR $\left(\mathrm{CD}_{3} \mathrm{OD}\right) \delta 11.1,12.4,13.5,13.9,13.9,15.6,21.1,24.6,36.3,38.6$, $39.9,42.0,52.5,56.3,71.5,74.0,74.1,75.0,77.2,81.9,85.0,92.0,101.0,109.0$, $112.5,126.4,127.6,128.2,130.0,130.5,130.6,130.6,130.8,130.9,131.1,134.0,136.0$, 138.4, 140.3, 141.0, 166.0, 177.9, 180.0, 202.3. Factumycin: yellow powder; HR-negative-FAB-MS $m / z 777.4332$ for $[\mathrm{M}-\mathrm{H}]^{-}$(calcd. for $\mathrm{C}_{44} \mathrm{H}_{61} \mathrm{~N}_{2} \mathrm{O}_{10}$, 777.4326); ${ }^{1} \mathrm{H}$ NMR $\left(\mathrm{CD}_{3} \mathrm{OD}\right) \delta 0.71(3 \mathrm{H}, \mathrm{d}, 7 \mathrm{~Hz}), 0.75(3 \mathrm{H}, \mathrm{s}), 0.92$ $(3 \mathrm{H}, \mathrm{s}) 0.95(3 \mathrm{H}, \mathrm{t}, 7 \mathrm{~Hz}), 1.62(3 \mathrm{H}, \mathrm{s}), 1.70(2 \mathrm{H}, \mathrm{m}), 1.74(3 \mathrm{H}, \mathrm{d}, 7 \mathrm{~Hz})$, $2.00(3 \mathrm{H}, \mathrm{s}), 2.10(1 \mathrm{H}, \mathrm{m}), 2.37(1 \mathrm{H}, \mathrm{m}), 2.90(1 \mathrm{H}, \mathrm{t}, 7 \mathrm{~Hz}), 3.13(3 \mathrm{H}, \mathrm{s}), 3.20$ $(3 \mathrm{H}, \mathrm{s}), 3.45(1 \mathrm{H}, \mathrm{d}), 3.70(1 \mathrm{H}, \mathrm{dd}), 3.86(1 \mathrm{H}, \mathrm{dd}), 4.15(1 \mathrm{H}, \mathrm{d}), 4.43(1 \mathrm{H}, \mathrm{dd})$, $5.49(1 \mathrm{H}, \mathrm{dq}, 10 \mathrm{~Hz}), 5.60(1 \mathrm{H}, \mathrm{m}), 5.64(1 \mathrm{H}, \mathrm{m}), 5.66(1 \mathrm{H}, \mathrm{m}), 5.92(1 \mathrm{H}, \mathrm{d})$, $5.96(1 \mathrm{H}, \mathrm{d}), 5.98(1 \mathrm{H}, \mathrm{m}), 6.28(1 \mathrm{H}, \mathrm{dd}), 6.46(1 \mathrm{H}, \mathrm{m}), 6.52(1 \mathrm{Hx} 2, \mathrm{~m}), 6.60$ $(1 \mathrm{H}, \mathrm{m}), 6.70(1 \mathrm{H}, \mathrm{m}), 6.80(1 \mathrm{H}, \mathrm{m}), 7.02(1 \mathrm{H}, \mathrm{d}), 7.36(1 \mathrm{H}, \mathrm{d}) ;{ }^{13} \mathrm{C}$ NMR $\left(\mathrm{CD}_{3} \mathrm{OD}\right) \delta 9.6,11.0,11.0,13.0,13.9,20.5,20.5,22.0,23.0,35.5,36.0,39.0$, $41.0,55.0,57.0,71.0,72.3,72.3,77.1,89.0,98.0,106.0,112.0,120.0,125.0$, $129.2,129.3,130.0,130.1,130.1,132.3,133.6,134.5,136.0,136.5,137.0,138.0$, $140.2,141.0,142.3,163.0,173.0,176.0,200.0$.

\section{Measurement of extracellular and intracellular T3SS-related proteins}

Wild-type EPEC was inoculated in Lysogeny broth medium and incubated at $37^{\circ} \mathrm{C}$ for $16 \mathrm{~h}$ without shaking. The overnight culture was diluted $(1: 25)$ in Dulbecco's modified Eagle's medium in the presence or absence of the presumed T3SS inhibitor, and the EPEC cultures were grown at $37^{\circ} \mathrm{C}$ in the presence of $5 \% \mathrm{CO}_{2}$ for $6 \mathrm{~h}$ without shaking. Secreted proteins released into the bacterial culture supernatant, and the whole-bacterial-cell lysates were prepared by TCA precipitation. Culture supernatants were filtered, and bacterial pellets were resuspended in distilled water. TCA was added to the respective samples at a final concentration of $10 \%$. After incubation of the samples on ice for $15 \mathrm{~min}$, they were centrifuged, and the resulting precipitated proteins were dissolved in SDS-polyacrylamide gel electrophoresis sample buffer.

\section{In vivo infection studies}

Female $\mathrm{C} 3 \mathrm{H} / \mathrm{HeJ}$ mice (6 weeks old) highly susceptible to $C$. rodentium ${ }^{41}$ were purchased from CLEA Japan (Tokyo, Japan) and kept for a week in an animal facility of Kitasato University. Infection of mice with $C$. rodentium was performed as reported previously. ${ }^{42}$ Briefly, C. rodentium was cultured overnight in Lysogeny broth medium at $37^{\circ} \mathrm{C}$. Thereafter, $200 \mu \mathrm{l}$ of bacterial suspension $\left(2 \times 10^{8}\right.$ c.f.u. per mouse $)$ was used to orally inoculate the mice by a gavage needle, followed by oral administration of aurodox (25 or $\left.100 \mathrm{mg} \mathrm{kg}^{-1}\right)$, tetracycline $\left(200 \mathrm{mg} \mathrm{kg}^{-1}\right.$ ) or $10 \%$ DMSO (as a control) for 1-4 days in a row. The mice were monitored for consecutive days after infection. To determine colon weight, three additional mice were inoculated and treated in the same manner as experimental and control mice. At 9 days 
after infection, the mice were killed and the distal colon $(5.5 \mathrm{~cm}$ length) ranging from the rectum was obtained. Colon specimens were washed with PBS to remove fecal pellets, and the colon weight was determined.

All animal experiments were conducted according to protocols approved by the Experimental Animal Center of the Kitasato University.

\section{Immunoblot analysis}

Secreted proteins and whole-bacterial-cell lysates were separated by SDSpolyacrylamide gel electrophoresis on $12 \%$ gels and transferred to polyvinylidene fluoride membranes (Millipore, Billerica, MA, USA). Proteins were analyzed by immunoblotting with anti-EspB, ${ }^{43}$ anti-EspF $\mathrm{F}^{42}$ and anti-GroEL (Sigma-Aldrich, St Louis, MO, USA) antibodies. For anti-Map antibodies, rabbits were immunized with Map-synthesized peptide (187-203 amino acids). Polyclonal antibodies were purified by affinity chromatography using antigenimmobilized columns. Specific protein signals were detected using a detection kit (ECL, GE Healthcare, Little Chalfont, Buckinghamshire, UK).

\section{ACKNOWLEDGEMENTS}

This work was supported in part by the Ministry of Education, Science, Sport and Culture of Japan through Grants-in-Aid for scientific research (B, 18390136 and 21390133) and scientific research on priority areas (19041066 and 21022045), and by a Grant-in-Aid for young scientists (B, 20790107). We are grateful to Mr Kengo Nakai for the taxonomy and fermentation of K06-0806 and to Ms Akiko Nakagawa, Ms Yumi Kawauchi, Ms Noriko Sato and Dr Kenichiro Nagai for mass and NMR spectra measurements.

1 Cornelis, G. R. \& Van Gijsegem, F. Assembly and function of type III secretory systems. Annu. Rev. Microbiol. 54, 735-774 (2000).

2 Bhavsar, A. P., Guttman, J. A. \& Finlay, B. B. Manipulation of host-cell pathways by bacterial pathogens. Nature. 449, 827-834 (2007).

3 Croxen, M. A. \& Finlay, B. B. Molecular mechanisms of Escherichia coli pathogenicity. Nat. Rev. Microbiol. 8, 26-38.

4 Donnenberg, M. S. \& Kaper, J. B. Enteropathogenic Escherichia coli. Infect. Immun. 60, 3953-3961 (1992).

5 McDaniel, T. K., Jarvis, K. G., Donnenberg, M. S. \& Kaper, J. B. A genetic locus of enterocyte effacement conserved among diverse enterobacterial pathogens. Proc. Nat Acad. Sci. USA 92, 1664-1668 (1995).

6 Dean, P. \& Kenny, B. The effector repertoire of enteropathogenic E.coli: ganging up on the host cell. Curr. Opin. Microbiol. 12, 101-109 (2009).

7 Warawa, J., Finlay, B. B. \& Kenny, B. Type III secretion-dependent hemolytic activity of enteropathogenic Escherichia coli. Infect. Immun. 67, 5538-5540 (1999).

8 Abe, A., Heczko, U., Hegele, R. G. \& Brett Finlay, B. Two enteropathogenic Escherichia coli type III secreted proteins, EspA and EspB, are virulence factors. J. Exp. Med. 188, 1907-1916 (1998).

9 Linington, R. G. et al. Caminoside A, an antimicrobial glycolipid isolated from the marine sponge Caminus sphaeroconia. Org. Lett. 4, 4089-4092 (2002).

10 Kauppi, A. M., Nordfelth, R., Hagglund, U., Wolf-Watz, H. \& Elofsson, M. Salicylanilides are potent inhibitors of type III secretion in Yersinia. Adv. Exp. Med. Biol. 529, 97-100 (2003).

11 Nordfelth, R., Kauppi, A. M., Norberg, H. A., Wolf-Watz, H. \& Elofsson, M. Small-molecule inhibitors specifically targeting type III secretion. Infect. Immun. $\mathbf{7 3}$ 3104-3114 (2005).

12 Bailey, L. et al. Small molecule inhibitors of type III secretion in Yersinia block the Chlamydia pneumoniae infection cycle. FEBS Lett 581, 587-595 (2007).

13 Muschiol, S. et al. A small-molecule inhibitor of type III secretion inhibits different stages of the infectious cycle of Chlamydia trachomatis. Proc. Natl Acad. Sci. USA 103, 14566-14571 (2006).

14 Muschiol, S., Normark, S., Henriques-Normark, B. \& Subtil, A. Small molecule inhibitors of the Yersinia type III secretion system impair the development of Chlamydia after entry into host cells. BMC Microbiol. 9, 75 (2009).

15 Veenendaal, A. K., Sundin, C. \& Blocker, A. J. Small-molecule type III secretion system inhibitors block assembly of the Shigella type III secreton. J. Bacteriol. 191, 563-570 (2009).

16 Tree, J. J. et al. Characterization of the effects of salicylidene acylhydrazide compounds on type III secretion in Escherichia coli 0157:H7. Infect. Immun. 77, 4209-4220 (2009).
17 Hudson, D. L. et al. Inhibition of type III secretion in Salmonella enterica serovar Typhimurium by small-molecule inhibitors. Antimicrob. Agents Chemother. 51, 2631-2635 (2007)

18 Negrea, A. et al. Salicylidene acylhydrazides that affect type III protein secretion in Salmonella enterica serovar Typhimurium. Antimicrob. Agents. Chemother. 51, 2867-2876 (2007).

19 Felise, H. B. et al. An inhibitor of Gram-negative bacterial virulence protein secretion. Cell. Host. Microbe. 4, 325-336 (2008).

20 Iwatsuki, M. et al. Guadinomines, type III secretion system inhibitors, produced by Streptomyces sp. K01-0509. II: physico-chemical properties and structure elucidation. J. Antibiot. 61, 230-236 (2008).

21 Iwatsuki, M. et al. Guadinomines, type III secretion system inhibitors, produced by Streptomyces sp. K01-0509. I: taxonomy, fermentation, isolation and biological properties. J. Antibiot. 61, 222-229 (2008).

22 Berger, J., Lehr, H., Teitel, S., Maehr, H. \& Grunberg, E. A new antibiotic X-5108 of Streptomyces origin. I. Production isolation and properties. J. Antibiot. 26, 15-22 (1973).

23 Gullo, V. P. et al. Factumycin, a new antibiotic (A40A): fermentation, isolation and antibacterial spectrum. J. Antibiot. 35, 1705-1707 (1982).

24 Kauppi, A. M., Nordfelth, R., Uvell, H., Wolf-Watz, H. \& Elofsson, M. Targeting bacterial virulence: inhibitors of type III secretion in Yersinia. Chem. Biol. 10, 241-249 (2003).

25 Bhuta, P. \& Chladek, S. Stimulation of Escherichia coli elongation factor Tu-dependent GTP hydrolysis by aminoacyl oligonucleotides in the presence of aurodox. FEBS Lett. 122, 113-116 (1980).

26 Wolf, H., Zahner, H. \& Nierhaus, K. Kirromycin, an inhibitor of the $30 \mathrm{~S}$ ribosomal subunits function. FEBS Lett. 21, 347-350 (1972).

27 Parmeggiani, A. \& Swart, G. W. Mechanism of action of kirromycin-like antibiotics. Annu. Rev. Microbiol. 39, 557-577 (1985).

28 Elliott, S. J. et al. The locus of enterocyte effacement (LEE)-encoded regulator controls expression of both LEE- and non-LEE-encoded virulence factors in enteropathogenic and enterohemorrhagic Escherichia coli. Infect. Immun. 68, 6115-6126 (2000).

29 Grant, A. J. et al. Co-ordination of pathogenicity island expression by the BipA GTPase in enteropathogenic Escherichia coli (EPEC). Mol. Microbiol. 48, 507-521 (2003).

30 Kenny, B. et al. Enteropathogenic E. coli (EPEC) transfers its receptor for intimate adherence into mammalian cells. Cell. 91, 511-520 (1997).

31 Abe, A. et al. Enteropathogenic Escherichia coli translocated intimin receptor, Tir, requires a specific chaperone for stable secretion. Mol. Microbiol. 33, 1162-1175 (1999).

32 Schauer, D. B. et al. Genetic and biochemical characterization of Citrobacter rodentium sp. nov. J Clin Microbiol. 33, 2064-2068 (1995)

33 Matsuzawa, T., Kuwae, A., Yoshida, S., Sasakawa, C. \& Abe, A. Enteropathogenic Escherichia coli activates the RhoA signaling pathway via the stimulation of GEF-H1. EMBO J. 23, 3570-3582 (2004).

34 Zhang, H. et al. Zelkovamycin, a new cyclic peptide antibiotic from Streptomyces sp. K96-0670. I. Production, isolation and biological properties. J Antibiot. 52, 29-33 (1999).

35 Shiring, E. \& Gottlieb, D. Methods for characterization of Streptomyces species. Intl. J. Syst. Bacteriol. 16, 313-340 (1966).

36 Becker, B., Lechevalier, M. P. \& Lechevalier, H. A. Chemical composition of cell-wall preparations from strains of various form-genera of aerobic Actinomycetes. Appl. Microbiol. 13, 236-243 (1965).

37 Collins, M. D., Pirouz, T., Goodfellow, M. \& Minnikin, D. E. Distribution of menaquinones in actinomycetes and corynebacteria. J. Gen. Microbiol. 100, 221-230 (1977).

38 Tamaoka, J., Katayama-Fujiwara, Y. \& Kuraishi, H. Analysis of bacterial menaquinone mixtures by high performance liquid chromatography. J. Appl. Bacteriol. 54, 31-36 (1983)

39 Liu, C. M., Williams, T. H. \& Pitcher, R. G. 13C-NMR studies on the biosynthesis of aurodox (antibiotic X-5108). J Antibiot 32, 414-417 (1979).

40 Dewey, R. S., Gullo, V. P., Zimmerman, S. B., Omura, S. \& Oiwa, R. (Merck \& Co., Inc.) A40A efrotomycin-like antibiotic in fermentation broth. US patent 4264607 April 28 (1981).

41 Vallance, B. A., Deng, W., Jacobson, K. \& Finlay, B. B. Host susceptibility to the attaching and effacing bacterial pathogen Citrobacter rodentium. Infect. Immun. 71, 3443-3453 (2003).

42 Nagai, T., Abe, A. \& Sasakawa, C. Targeting of enteropathogenic Escherichia coli EspF to host mitochondria is essential for bacterial pathogenesis: critical role of the 16th leucine residue in EspF. J. Biol. Chem. 280, 2998-3011 (2005).

43 Sekiya, K. et al. Supermolecular structure of the enteropathogenic Escherichia colitype III secretion system and its direct interaction with the EspA-sheath-like structure. Proc. Nat/ Acad. Sci USA 98, 11638-11643 (2001). 